$\begin{array}{rr}\text { FIT(PATOLOGI } & \text { Volume } 10, \text { Nomor 4, Agustus } 2014 \\ \text { I N D ONESIA } & \text { Halaman 112-118 } \\ \text { ISSN: } 0215-7950 & \text { DOI: } 10.14692 / \text { jfi.10.4.112 }\end{array}$

\title{
Respons Lima Varietas Kacang Panjang terhadap Bean common mosaic virus
}

\author{
Response of Five Varieties of Yard Long Bean to \\ Bean common mosaic virus
}

\author{
Harwan Susetio, Sri Hendrastuti Hidayat* \\ Institut Pertanian Bogor, Bogor 16680
}

\begin{abstract}
ABSTRAK
Insidensi penyakit mosaik kuning pada tanaman kacang panjang dilaporkan terjadi secara meluas di beberapa daerah di Jawa Barat dan Jawa Tengah pada tahun 2008-2009. Penyebab utama penyakit mosaik kuning tersebut ialah Bean common mosaic virus (BCMV) yang bersifat tular benih dan dapat ditularkan melalui kutudaun. Penelitian ini bertujuan untuk menentukan respons lima varietas kacang panjang (Vigna sinensis), yaitu varietas Parade, New Jaliteng, Long Silk, Super Sainan, dan Pilar terhadap infeksi BCMV. Tanaman kacang panjang diinokulasi BCMV secara mekanis dan dilakukan pengamatan terhadap insidensi dan keparahan penyakit, periode inkubasi, waktu pembungaan, dan bobot polong per tanaman. Lima varietas kacang panjang yang diuji menunjukkan respons rentan terhadap infeksi BCMV. Periode inkubasi berkisar 6-16 hari, insidensi penyakit mencapai 90-100\%, keparahan penyakit berkisar 49.1-69.7\%. Infeksi BCMV menyebabkan gejala berat berupa malformasi daun dan kekerdilan tanaman. Tanaman terinfeksi mengalami penundaan waktu berbunga berkisar antara $2-5$ hari dan penurunan bobot polong per tanaman mencapai $46.6 \%$. Program pemuliaan tanaman untuk mengembangkan varietas tahan BCMV sangat diperlukan.
\end{abstract}

Kata kunci: ELISA, penyakit mosaik kuning, Potyvirus, tular benih

\begin{abstract}
Incidence of yellow mosaic disease on yard long bean occurred widely in some areas in West and Central Java in 2008-2009. The causal agent of this disease is Bean common mosaic virus (BCMV) which can be transmitted through seed and aphids. Research was conducted to determine response of five varieties of yard long bean (Vigna sinensis), i.e. Parade, New Jaliteng, Long Silk, Super Sainan, and Pilar to BCMV infection. Yard long bean plants was inoculated by BCMV mechanically, followed by observation of disease incidence and severity, incubation period, flowering time, and yield. All five varieties of yard long bean showed susceptible response to BCMV infection. Incubation period was 6-16 days, disease incidence was $90-100 \%$, and disease severity was 49.1-69.7\%. BCMV infection caused severe symptoms of leaf malformation and plant stunting. Flowering time was delayed $2-5$ days on infected plants and yield was decreased up to $46.6 \%$. Breeding program to develop resistance varieties to BCMV is necessary.
\end{abstract}

Key words: ELISA, Potyvirus, seed borne, yellow mosaic disease

*Alamat penulis korespondensi: Departemen Proteksi Tanaman, Fakultas Pertanian, Institut Pertanian Bogor Jalan Kamper, Kampus Darmaga IPB, Bogor 16680

Tel: 0251-8629364, Faks: 0251-8629362, Surel: srihendrastutihidayat@gmail.com 


\section{PENDAHULUAN}

Pada tahun 2008-2009 dilaporkan terjadi ledakan penyakit mosaik kuning pada tanaman kacang panjang di beberapa daerah di Jawa Barat dan Jawa Tengah. Damayanti et al. (2009) melaporkan bahwa penyebab utama penyakit mosaik kuning di Jawa Barat (Bogor, Karawang, Subang, Indramayu, dan Cirebon) dan Jawa Tengah (Tegal dan Pekalongan) ialah Bean common mosaic virus-black eye cowpea (BCMV-BIC) yang menginfeksi secara tunggal atau bersama dengan Cucumber mosaic virus (CMV). Gejala BCMV ditunjukkan dengan mosaik berupa lepuhan, pola warna kuning dan hijau pada daun, tulang daun menguning, bercak dan malformasi. Tanaman yang terinfeksi dapat menjadi kerdil, menghasilkan hanya sedikit polong, dan masak lebih lambat dibandingkan dengan polong yang tidak terinfeksi.

Bean common mosaic virus (BCMV) termasuk famili Potyviridae, genus Potyvirus. Beberapa anggota Potyvirus dilaporkan menginfeksi tanaman kacang-kacangan yang secara ekonomis sangat penting karena ditularkan melalui benih dan menyebar secara alami melalui kutudaun secara nonpersisten. Beberapa spesies kutudaun yang dapat menularkan BCMV diantaranya Aphis craccivora, A. gossypii, dan Myzus persicae (McKern et al. 1992).

Strategi pengendalian virus, termasuk BCMV umumnya mengandalkan penggunaan benih sehat,menghilangkantanamanterinfeksi, menggunakan varietas tahan, dan aplikasi insektisida untuk mengendalikan serangga vektor. Sebagai upaya untuk memperoleh informasi yang lebih lengkap untuk mengatasi permasalahan penyakit mosaik kuning kacang panjang maka dilakukan evaluasi respons beberapa varietas kacang panjang terhadap infeksi BCMV.

\section{BAHAN DAN METODE}

\section{Perbanyakan Inokulum BCMV}

Isolat BCMV yang digunakan ialah isolat asal Cirebon yang diperoleh dari Laboratorium
Virologi, Departemen Proteksi Tanaman IPB. Sumber inokulum ditularkan secara mekanis pada tanaman kacang panjang varietas Parade berumur 1 minggu setelah tanam (MST). Cairan perasan tanaman dibuat dengan menggerus daun muda yang terinfeksi virus sebanyak $0.5 \mathrm{~g}$ dalam $0.01 \mathrm{M}$ bufer fosfat $(\mathrm{pH} \mathrm{7)}$ yang mengandung $\beta$-merkapto etanol $2 \%$ dengan perbandingan 1:10 (b/v). Cairan perasan tersebut dioleskan pada permukaan daun yang sudah ditaburi dengan carborundum 600 mesh. Permukaan daun yang sudah diberi perlakuan dibilas menggunakan air destilata yang mengalir.

\section{Inokulasi BCMV pada Lima Varietas Kacang Panjang}

Tanaman kacang panjang yang digunakan dalam penelitian terdiri atas 5 varietas, yaitu Parade, New Jaliteng, Long Silk, Super Sainan, dan Pilar. Benih kacang panjang ditanam pada pot kantong plastik yang sudah berisi tanah dan pupuk kandang dengan perbandingan 2:1 (b/b). Setiap pot kantong plastik ditanami 3 benih dengan kedalaman $2 \mathrm{~cm}$. Penyiangan dan pemilihan 1 bibit terbaik untuk tahapan selanjutnya dilakukan pada umur 1 MST.

Tanaman kacang panjang diinokulasi dengan metode inokulasi mekanis seperti diuraikan sebelumnya. Setelah inokulasi tanaman dipelihara di rumah kaca. Pengamatan dilakukan terhadap periode inkubasi penyakit, insidensi dan keparahan penyakit, waktu pembungaan, jumlah bunga, dan bobot polong per tanaman.

\section{Deteksi Virus}

Metode yang digunakan untuk deteksi virus ialah metode enzyme-linked immunosorbent assay (ELISA) tidak langsung (indirectELISA), menggunakan antiserum Potyvirus (Agdia, USA). Deteksi virus dilakukan pada minggu ke-2 dan ke-4 setelah inokulasi.

Tahap ELISA diawali dengan penyiapan cairan perasan tanaman. Daun tanaman digerus menggunakan mortar dengan menambahkan bufer ekstrak dengan perbandingan 1:100 (v/v). Sebanyak $100 \mu \mathrm{L}$ cairan perasan 
diisikan ke dalam sumuran pelat ELISA. Pelat ELISA diinkubasi semalam pada suhu $4{ }^{\circ} \mathrm{C}$, setelah itu pelat dicuci sebanyak 7 kali dengan phosphate buffer saline tween 20 (PBST). Tiap sumuran kemudian diisi dengan $100 \mu \mathrm{L}$ antiserum BCMV (1:200). Pelat diinkubasi kembali pada suhu ruang $24^{\circ} \mathrm{C}$ selama 2 jam, kemudian pelat dicuci sebanyak 8 kali dengan PBST. Sumuran pelat selanjutnya diisi $100 \mu \mathrm{L}$ enzim konjugat goat anti-rabbit yang telah dilabel enzim alkaline phosphate (RaM-AP) dalam conjugate buffer dan diinkubasi selama 1 jam pada suhu ruang $24{ }^{\circ} \mathrm{C}$. Pelat kemudian dicuci dengan PBST sebanyak 8 kali. Setiap sumuran diisi dengan $100 \mu \mathrm{L}$ substrat P-nitrophenylphosphate (PNP) dan diinkubasi selam 30-60 menit pada suhu ruang. Perubahan warna diamati pada masingmasing sumuran. Apabila warna telah berubah menjadi kuning, reaksi segera dihentikan dengan menambahkan $50 \mu \mathrm{L} \mathrm{NaOH} 3 \mathrm{M}$. Hasil ELISA dianalisis secara kuantitatif dengan ELISA reader (BIO-RAD Model 550) pada panjang gelombang $405 \mathrm{~nm}$.

\section{Rancangan Percobaan dan Pengamatan}

Rancangan percobaan yang digunakan ialah rancangan acak lengkap (RAL). Perlakuan terdiri atas 5 varietas kacang panjang, yaitu Parade, New Jaliteng, Long Silk, Super Sainan, dan Pilar. Setiap varietas tanaman diulang sebanyak 10 kali, untuk masing-masing varietas terdapat kontrol dengan 10 ulangan. Data yang diperoleh dianalisis dengan sidik ragam (ANOVA) dengan taraf nyata $5 \%$. Pengaruh perlakuan yang berbeda nyata diuji lanjut dengan uji selang berganda Duncan (DMRT) dengan taraf nyata $5 \%$. Data diolah dengan program Statistical Analysis System (SAS) versi 9.1.3.

Pengamatan terdiri atas insidensi dan keparahan penyakit, periode inkubasi, waktu berbunga, dan bobot polong per tanaman. Insidensi dan keparahan penyakit dihitung mengikuti rumus sebagai berikut :

$$
\mathrm{IP}=\mathrm{n} / \mathrm{N} \times 100 \% \text {, dengan }
$$

IP, insidensi penyakit; $n$, jumlah tanaman bergejala; $N$, jumlah tanaman yang diamati.

$$
\mathrm{KP}=\frac{\sum(\mathrm{n} \times \mathrm{v})}{(\mathrm{Z} \times \mathrm{N})} \times 100 \%, \text { dengan }
$$

KP, keparahan penyakit; $n$, jumlah bagian tanaman yang diamati pada kategori serangan tertentu; v, nilai kategori serangan; $\mathrm{Z}$, nilai skala kategori serangan tertinggi; $N$, jumlah seluruh bagian yang diamati.

Kategori serangan dibedakan menjadi skor $0,1,2,3$, dan 4 dengan deskripsi gejala berturut-turut tanaman tidak bergejala, gejala mosaik ringan dengan pemucatan tulang daun, gejala mosaik sedang, gejala mosaik berat, dan malformasi daun, atau tanaman kerdil.

Periode inkubasi virus dalam tanaman ialah waktu timbulnya gejala, dari mulai inokulasi sampai terlihat gejala pertama. Waktu berbunga ialah waktu munculnya bunga pertama (bakal bunga), jumlah bunga yang muncul dihitung sampai 4 minggu setelah masa berbunga. Bobot polong per tanaman dihitung mulai dari kacang panjang siap panen yaitu pada saat tanaman berumur 60-70 hari. Polong yang tepat untuk dipanen yaitu berwarna hijau segar dan polongnya masih padat. Tanaman kacang panjang dapat dipanen beberapa kali, dengan interval panen dilakukan seminggu sekali berjalan sampai masa produktif terhenti atau setelah tanaman berumur 4 bulan.

\section{HASIL}

\section{Respons Lima Varietas Kacang Panjang terhadap Infeksi BCMV}

Infeksi BCMV mulai terlihat pada 6 hari setelah inokulasi (HSI) pada varietas Parade, sedangkan gejala paling lama muncul pada varietas Long Silk, yaitu 16 HSI (Tabel 1). Gejala pertama kali muncul berupa pemucatan tulang daun (vein clearing) pada daun-daun muda, mengakibatkan jaringan sekitarnya mengalami klorosis, menjadi hijau muda, kemudian berkembang menjadi mosaik kuning disertai dengan malformasi daun. Gejala akan berkembang menjadi lebih parah, yaitu tulang daun akan mengerut sehingga daun bergelombang dan permukaan daun tidak merata. Gejala lanjut berupa 
pelepuhan daun dan pengerdilan tanaman (Gambar 1). Semua varietas menunjukkan gejala malformasi. Kacang panjang Super Sainan dan Pilar menunjukan gejala yang lebih parah dibandingkan dengan 3 varietas lainnya karena tanaman yang terinfeksi mengalami pengerdilan. Insidensi penyakit dan keparahan penyakit pada 5 varietas berturut-turut berkisar 72.5-100\% dan 49.1-63.8\% (Tabel 1). Insidensi dan keparahan penyakit yang tertinggi terjadi pada varietas Parade, sedangkan yang terendah terjadi pada varietas Long Silk.

Titer virus pada tanaman terinfeksi diukur pada 2 MSI dan 4 MSI menggunakan metode ELISA. Nilai absorbansi ELISA (NAE) pada 2 MSI lebih tinggi dibandingkan dengan pada 4 MSI. Penurunan NAE pada 5 varietas kacang panjang berkisar antara $15.4-79.1 \%$ dengan penurunan tertinggi terjadi pada varietas Pilar (Tabel 2).

\section{Pembungaan dan Bobot Polong}

Tanaman kacang panjang yang terinfeksi BCMV mengalami penghambatan waktu berbunga dibandingkan dengan tanaman sehat. Hal tersebut terutama tampak pada varietas Long Silk, Super Sainan, dan Pilar (Tabel 3). Jumlah bunga yang terbentuk lebih rendah pada tanaman terinfeksi dibandingkan tanaman sehat, terutama untuk varietas Parade.

Varietas Parade memiliki potensi bobot polong paling tinggi dibandingkan dengan varietas lainnya sedangkan varietas Super Sainan potensi bobot polongnya paling rendah

Tabel 1 Periode inkubasi, insidensi penyakit, dan keparahan penyakit mosaik kuning pada varietas kacang panjang yang diinokulasi Bean common mosaic virus

\begin{tabular}{lccc}
\hline Varietas & $\begin{array}{c}\text { Periode inkubasi } \\
(\text { HSI })\end{array}$ & $\begin{array}{c}\text { Insidensi penyakit } \\
(\%)\end{array}$ & $\begin{array}{c}\text { Keparahan penyakit } \\
(\%)\end{array}$ \\
\hline Parade & 6 & 100 & 63.8 \\
New Jaliteng & 10 & 95 & 58.4 \\
Long Silk & 16 & 72.5 & 49.1 \\
Super Sainan & 14 & 88.8 & 69.7 \\
Pilar & 10 & 88.8 & 51.9 \\
\hline
\end{tabular}

* Insidensi dan keparahan penyakit diukur pada 8 minggu setelah inokulasi

HSI, hari setelah inokulasi

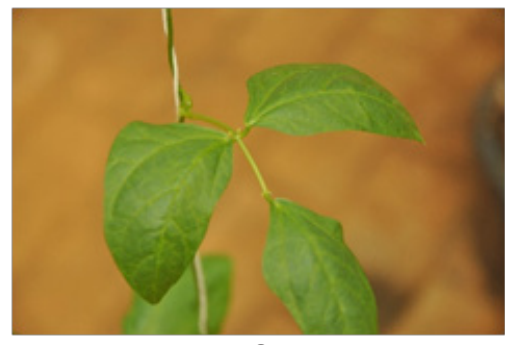

a

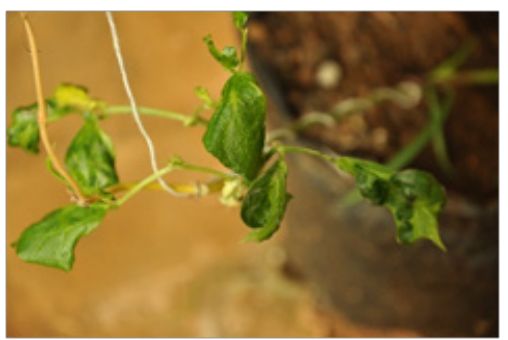

d

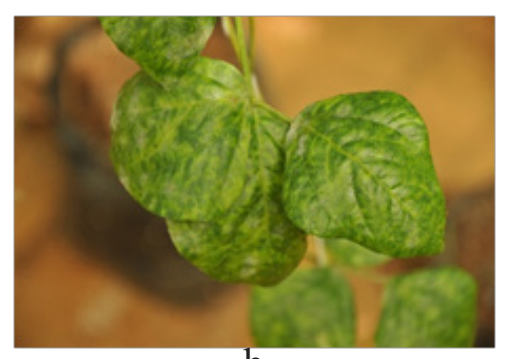

b

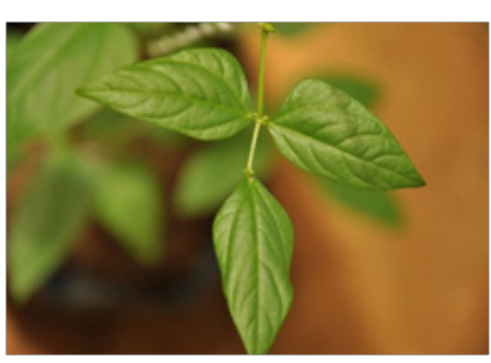

e

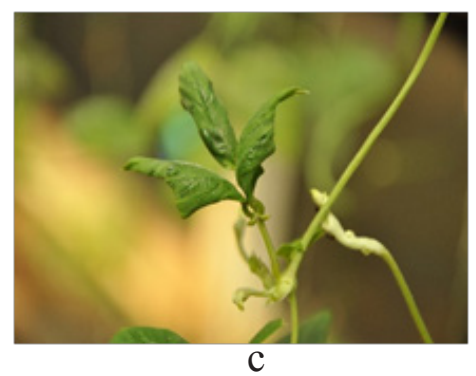

Gambar 1 Gejala infeksi Bean common mosaic virus pada tanaman kacang panjang. a, mosaik ringan; b, mosaik sedang; c, mosaik berat dan daun mengecil; $d$, malformasi daun dan pengerdilan tanaman; e, daun tanaman sehat. 
Tabel 2 Nilai absorbansi ELISA (NAE) varietas kacang panjang yang diinokulasi Bean common mosaic virus

\begin{tabular}{lccc}
\hline Varietas & 2 MSI $^{*}$ & M MSI $^{*}$ & Penurunan NAE (\%) \\
\hline Parade & $0.34 \pm 0.11 \mathrm{~b}$ & $0.11 \pm 0.00 \mathrm{a}$ & 67.7 \\
New Jaliteng & $0.41 \pm 0.23 \mathrm{~b}$ & $0.32 \pm 0.19 \mathrm{a}$ & 22.1 \\
Long Silk & $0.47 \pm 0.21 \mathrm{~b}$ & $0.32 \pm 0.02 \mathrm{a}$ & 31.1 \\
Super Sainan & $0.47 \pm 0.18 \mathrm{~b}$ & $0.39 \pm 0.01 \mathrm{a}$ & 15.4 \\
Pilar & $2.13 \pm 0.98 \mathrm{a}$ & $0.45 \pm 0.14 \mathrm{a}$ & 79.1 \\
\hline
\end{tabular}

*Angka dalam kolom yang sama diikuti huruf yang sama tidak berbeda nyata berdasarkan uji Duncan pada taraf 5\% MSI, minggu setelah inokulasi

Tabel 3 Waktu berbunga dan jumlah bunga tanaman kacang panjang yang diinokulasi Bean common mosaic virus

\begin{tabular}{lccccc}
\hline \multirow{2}{*}{ Varietas } & \multicolumn{2}{c}{ Waktu berbunga $(\mathrm{HST})^{*}$} & & \multicolumn{2}{c}{ Jumlah bunga $^{*}$} \\
\cline { 2 - 3 } \cline { 5 - 6 } & Tanaman sehat & Tanaman terinfeksi & & Tanaman sehat & Tanaman terinfeksi \\
\hline Parade & $35.70 \pm 2.06 \mathrm{c}$ & $38.20 \pm 2.78 \mathrm{bc}$ & & $16.1 \pm 4.38 \mathrm{a}$ & $9.50 \pm 1.17 \mathrm{~b}$ \\
New Jaliteng & $38.00 \pm 2.62 \mathrm{c}$ & $41.55 \pm 3.09 \mathrm{bc}$ & & $9.00 \pm 1.41 \mathrm{bc}$ & $6.66 \pm 1.73 \mathrm{~cd}$ \\
Long Silk & $43.50 \pm 4.27 \mathrm{a}$ & $47.00 \pm 9.02 \mathrm{~b}$ & & $5.50 \pm 2.44 \mathrm{~cd}$ & $6.00 \pm 3.58 \mathrm{~cd}$ \\
Super Sainan & $43.37 \pm 4.97 \mathrm{a}$ & $48.66 \pm 8.12 \mathrm{~b}$ & & $7.62 \pm 3.08 \mathrm{~cd}$ & $6.66 \pm 3.88 \mathrm{~cd}$ \\
Pilar & $42.71 \pm 4.11 \mathrm{a}$ & $47.00 \pm 6.02 \mathrm{~b}$ & & $6.00 \pm 0.57 \mathrm{~cd}$ & $4.30 \pm 2.58 \mathrm{~d}$ \\
\hline
\end{tabular}

*Angka dalam kolom yang sama diikuti huruf yang sama tidak berbeda nyata berdasarkan uji Duncan pada taraf 5\% HST, hari setelah tanam

(Tabel 4). Infeksi BCMV dapat menyebabkan penurunan bobot polong yang cukup besar, yaitu berkisar 27.1-85.2\%. Penurunan bobot polong terendah terjadi pada varietas Parade walaupun varietas Parade mengalami penurunan jumlah bunga yang paling banyak.

\section{PEMBAHASAN}

Respons lima varietas kacang panjang yang diuji pada penelitan ini tergolong rentan berdasarkan periode inkubasi, insidensi dan keparahan penyakit. Periode inkubasi, insidensi dan keparahan penyakit diukur berdasarkan gejala yang muncul dan menandakan ke-mampuan virus untuk berkembang dan ber-gerak di dalam jaringan tanaman (Kareem dan Taiwo 2007). Walaupun demikian, Strausbaugh et al. (2003) menyatakan bahwa pengelompokkan respons varietas terhadap BCMV galur NL3K sulit dilakukan bila hanya didasarkan pada perkembangan gejala. Disarankan empat parameter yang harus digunakan untuk melakukan skrining ketahanan tanaman terhadap BCMV, yaitu kemunculan gejala sistemik, kebugaran tanaman, titer virus, dan bobot kering tanaman. Varietas yang resisten hanya menunjukkan gejala pada daun yang diinokulasi, dan tanaman tidak terganggu pertumbuhannya. Varietas yang rentan ditandai oleh gejala sistemik yang muncul pada daun trifoliat dan titer virus yang tinggi dengan NAE $>1.0$.

Gejala yang muncul pada lima varietas kacang panjang yang diuji termasuk gejala sistemik dengan keparahan penyakit yang cukup tinggi. Walaupun demikian, titer virus yang diukur berdasarkan NAE termasuk rendah. Hal tersebut merupakan fenomena yang umum terjadi pada infeksi virus. Titer virus tidak selalu berkorelasi dengan gejala, sehingga untuk menentukan respons ketahanan tanaman harus menggunakan beberapa parameter (Strausbaugh et al. 2003). Pengamatan terhadap gejala dan periode inkubasi umumnya dilakukan untuk pengujian kisaran inang virus. Naderpour et al. (2010) melaporkan beberapa tanaman inang BCMV dengan jenis gejala yang berbeda, yaitu 
Tabel 4 Bobot polong per tanaman pada tanaman kacang panjang yang diinokulasi Bean common mosaic virus

\begin{tabular}{lccc}
\hline Varietas & $\begin{array}{c}\text { Tanaman sehat } \\
(\mathrm{g})^{*}\end{array}$ & $\begin{array}{c}\text { Tanaman terinfeksi } \\
(\mathrm{g})^{*}\end{array}$ & $\begin{array}{c}\text { Penurunan bobot } \\
(\%)\end{array}$ \\
\hline Parade & $27.57 \pm 9.76 \mathrm{a}$ & $20.11 \pm 5.03 \mathrm{ab}$ & 27.1 \\
New Jaliteng & $25.69 \pm 6.22 \mathrm{a}$ & $16.20 \pm 6.16 \mathrm{bc}$ & 36.9 \\
Long Silk & $15.39 \pm 7.78 \mathrm{bc}$ & $8.54 \pm 3.02 \mathrm{cde}$ & 44.5 \\
Super Sainan & $8.39 \pm 3.71 \mathrm{cde}$ & $1.25 \pm 1.99 \mathrm{e}$ & 85.2 \\
Pilar & $11.58 \pm 3.98 \mathrm{~cd}$ & $7.03 \pm 3.66 \mathrm{de}$ & 39.3 \\
\hline
\end{tabular}

*Angka dalam kolom yang sama diikuti huruf yang sama tidak berbeda nyata berdasarkan uji Duncan pada taraf nyata $5 \%$

Chenopodium quinoa, C. amaranticolor, dan $P$. vulgaris cv. Red Kidney dengan gejala lesio lokal klorotik; sedangkan $P$. vulgaris var. Bountiful dan P. vulgaris var. Stringless Green Refugee dengan gejala mosaik dan malformasi. Lebih lanjut dilaporkan bahwa tipe gejala penyakit yang disebabkan oleh BCMV ditentukan oleh galur BCMV, suhu, dan genotipe tanaman inang. Lebih dari 15 galur BCMV yang telah diketahui diantaranya Blackeye, US1, US5, NL2, NL3, NL4, NL5, NL6, NL7 dan NL8 (McKernet al. 1992).

Insidensi penyakit mosaik kuning pada tanaman kacang panjang di beberapa daerah di Jawa Barat dan Jawa Tengah menyebabkan kehilangan hasil yang sangat nyata. Keparahan penyakit yang terjadi di lapangan tersebut disebabkan oleh penggunaan benih yang membawa virus, aktivitas serangga vektor, dan infeksi campuran BCMV dan CMV (Damayanti et al. 2009). Potensi infeksi BCMV terhadap kehilangan hasil kacang panjang belum diketahui. Dilaporkan oleh Li et al. (2014) bahwa infeksi BCMV secara tunggal pada tanaman Vigna agularis di Changping, Beijing mampu menyebabkan kehilangan hasil berkisar 50-95\%. Penurunan bobot polong yang terjadi pada kacang panjang (Parade, New Jaliteng, Long Silk, Super Sainan, dan Pilar) menunjukkan adanya gangguan fisiologis tanaman karena infeksi BCMV. Selain penurunan bobot polong, infeksi BCMV juga menyebabkan waktu berbunga terlambat dan jumlah bunga menurun. Perlakuan inokulasi BCMV pada awal fase vegetatif tanaman menyebabkan gangguan yang berat terhadap proses fotosintesis. Infeksi Cowpea yellow mosaic virus pada tanaman kacang tunggak menyebabkan penurunan hasil $40-60 \%$ bila tanaman diinokulasi pada 7 hari setelah tanam, tetapi hasil hanya menurun 10 $15 \%$ bila tanaman diinokulasi pada saat fase pembungaan (Kareem dan Taiwo 2007). Hal tersebut menunjukkan bahwa kehilangan hasil akan semakin tinggi bila tanaman terinfeksi sejak awal pertumbuhan.

Pengendalian penyakit mosaik kuning pada kacang panjang perlu dilakukan untuk menghindari infeksi awal dan kehilangan hasil. Penyediaan benih bebas virus, pengendalian serangga vektor, dan penanaman varietas tahan diharapkan dapat diterapkan untuk menjaga stabilitas produksi pertanian. Program pemuliaan tanaman untuk menghasilkan varietas tahan dan program sertifikasi benih untuk menyediakan benih bebas virus perlu mendapat perhatian.

\section{DAFTAR PUSTAKA}

Damayanti TA, Alabi OJ, Rayapati NA, Rauf A. 2009. Severe outbreak of a yellow mosaic disease on the yard long bean in Bogor, West Java. Hayati J Biosci. 16(2):78-82.

Kareem KT, Taiwo MA. 2007. Interactions of viruses in cowpea: effects on growth and yield parameters. Vir J. 4:15. DOI:10.1186/1743-422x-4-15.

Li YQ, Liu ZP, Yang K, Li YS, Zhao B. 2014. First report of Bean common mosaic virus 
infecting Azuki bean (Vigna angularis) in China. Plant Dis. 98(7):1.017.1. DOI: 10.1094/PDIS-01-14-0064-PDN.

McKern NM, Mink GI, Barnett OW, Mishra A, Whittaker LA, Silbernagel MJ, Ward CW, Shukla DD. 1992. Isolates of Bean common mosaic virus comprising two distinct Potyviruses. Phytopathology. 82(9):923-929.

Naderpour M, Mohammadi M, Mossahebi GH, Koohi-Habibi M. 2010. Identification of three strains of Bean common mosaic necrosis virus in common bean from Iran. Plant Dis. 94(1):127.1. DOI: 10.1094/ PDIS-94-1-0127A.

Strausbaugh CA, Myers JR, Forster RL, McClean PE. 2003. A Quantitative method to screen common bean plants for resistance to Bean common mosaic necrosis virus. Phytopathology. 93(11):1430-1436. DOI: 10.1094/PHYTO.2003:93.11.1430. 